This is our version of the article. It was later published as:

Heimans, S., \& Singh, P. (2016). Re-presenting, performing critical/post-critical research realities Research in Education, pages 1-17.

DOI: 10.1177/0034523716664606;

http://rie.sagepub.com/content/early/2016/09/16/0034523716664606.full.pdf?ijkey=BqnjeQ2NyCIZYZ

h\&keytype=finite

\title{
Re-presenting, performing critical/post-critical research realities
}

\section{Stephen Heimans and Parlo Singh}

Griffith Institute for Educational Research, Griffith University, Brisbane, Australia

\section{Corresponding Author:}

Stephen Heimans

Griffith Institute for Educational Research

Mt Gravatt campus, Griffith University

176 Messines Ridge Road, Mt Gravatt,

Brisbane, Queensland 4122, Australia

Email: s.heimans@griffith.edu.au 


\begin{abstract}
:
The aim of this paper is to focus on the relations between theory and research methods in educational research by mapping out our own research journeys. The paper arises out of a plenary talk at a "Theory Workshop” (13-15 May, 2016) that the Australian Association for Educational Research (AARE) facilitated with Griffith University in Brisbane. This introductory talk attempted to create the space for 'opening up' discussion about the complex relations between theory and methods, and to show how these complex relations have been realised in our own, very different, researcher trajectories. It was a 'contradictoryperformance' - we conducted a dialogue, invited interruptions, meandered from the central issue of theorymethod nexus, talked past one another, worked with a chaotic PowerPoint presentation (slides from which are included here) and so on. We wanted the talk to be messy and, in both its form and contents, to be an invitation to others to engage in similar ways during the weekend. We were also interested in connecting and disconnecting with some of the recent debates in education research, for example on experimental practices, performativity, new materiality, and post-qualitative research. Drawing on these debates and on our own research work we wanted to create the space for considering our research in terms of their disjunctive 'journeys' and in terms of the consequences (and therefore to think about the purposes of research, and relatedly the purposes of education) of this contradictory work. This article is a reworked version of this talk - but we have tried to keep its open 'feel' in the hope of inviting other conversations about, and connections with and between, theory and methods.
\end{abstract}




\section{Introduction}

This paper arises out of a recent “Theory Workshop” (13-15 May, 2016) that the Australian Association for Educational Research (AARE) facilitated with Griffith University in Brisbane. The workshop is one of a series of three that AARE offers each year to postgraduate and early career researchers in education. The theme of this particular workshop, which was negotiated between Griffith University researchers and the AARE, was the Theory-Method Nexus. We, the authors of this paper, gave the opening plenary at the workshop and the work we have undertaken here is based on this talk.

Our purpose in giving the plenary talk was to attempt to create the space for 'opening up' discussion about the complex relations between theory and methods, and to show how these complex relations have been realised in our own, very different, researcher trajectories. The plenary talk was a 'contradictoryperformance' - we conducted a dialogue, invited interruptions, meandered from the central issue of theorymethod nexus, track, talked past one another, worked with a chaotic PowerPoint presentation (slides from which are included here) and so on. We wanted the talk to be messy and, in both its form and contents, to be an invitation to others to engage in similar ways during the weekend. We were also interested in connecting and disconnecting with some of the recent debates in education research, for example on experimental practices (Whatmore \& Landström, 2011), performativity (Barad, 2003), new materiality (Heimans, 2015), and post-qualitative research (St. Pierre, 2011. Drawing on these debates and on our own research work (see Heimans, 2011, 2012; Heimans et al., 2015; Singh et al., 2014), we wanted to create the space for considering our research in terms of their disjunctive 'journeys' and in terms of the consequences (and therefore to think about the purposes of research, and relatedly the purposes of education) of this contradictory work.

The broader context for our thinking in this article/presentation has developed out of our research on the relations between education (and policy), schooling and research and our feeling that these relations have never been more fraught, and more subject to external evaluation/inspection, and consequently, they are more critical to understand and discuss. Minimally, there are several converging factors that contribute to this situation. In Australia, schooling continues to fail to deliver fully on its promises to people living in poverty. As a result, the hope that education (and research) offers is, for many, a thwarted, cruel optimism 
(Berlant, 2011). Concurrently, education and research, in their institutionalised forms (in schools and universities), are enmeshed into the public-privatising of neo-liberalising governance practices. In this public-privatising mélange, there is a focus on schools and universities to perform, or more accurately, to display how well they are doing, in terms of measures, data and metrics. Governance of research and schooling through data-driven accountability measures is shaping and reforming schooling, teaching, learning and research in market-driven directions. Further to this, and relatedly, there is a growing disillusionment with the promises and (lack of) impact of critical and qualitative scholarship to enact the change that is urgently required. We urgently need theoretical, methodological and 'on the ground' articulations of 'what is next', 'post' the critical, not to dismiss it, but, rather, as a way, ironically, of attempting to fulfil whatever ambitions the critical held. In this paper then, and in this context, we explore our own journeys through the critical and beyond as we map out, re-present/perform, our theory-method nexus journeys.

\section{Presentation}

\section{Introduction}

Parlo: My name is Parlo Singh. I am a Professor of Education at Griffith University, Brisbane, Australia and have been working in the field of educational research since I was awarded my PhD in January 1993. Since that time I have worked on a number of large-scale research projects dealing with issues of educational inequality, disadvantage and cultural identity.

(Turn to Stephen .....)

Stephen: I am a postdoctoral research fellow at Griffith University, Brisbane, Australia and Lecturer in Education at University of New England. Armidale, Australia. I have been 'involved' in education since 1984, but only in research since 2009, when I started my PhD. My PhD research focused on education policy.

Parlo: As we do this talk/dialogue/enactment we are conscious that we are not simply representing a map of our research journeys. Although we settled on using the mapping metaphor to talk about re-presentation and performativity, the maps that we produced are very different, and constantly changed as we wrote, rewrote and spoke together about the research-method nexus. We wondered if the mapping of the research problem 
(theory-method nexus) was one dimensional. Perhaps we needed to consider other dimensions? Perhaps we needed to consider a street view map, an aerial map, an underground map, a travelling map, a multidimensional map, a song line, and then worry about the different kinds of realities produced through these mapping exercises.

We wondered about the relation between the various maps that we drew of our respective research journeys, the actual research journeys, and the articulations of these maps in a 'dialogic' plenary presentation? Here we encounter a simple (but devastatingly consequential) idea; that is, that the mapping exercise produces or performs realities (see Law, 2004). This is an important point. We did not think then that these different maps produced different perspectives on a singular reality. Rather, we became aware of 'thinking through' (in at least two senses) the different emergent realities that might be produced through the mapping exercise. So, perhaps, the mapping stories are not simply re-presentations - good, poor, bad representations of our research journeys (see Thrift , 2008 for an excellent introduction to nonrepresentational theory).

\section{Research journeys}

Parlo: In 1996 I receive funding from the Australian Research Council Discovery scheme to undertake my first scale research project. The project is about the construction of Australian identities for two recent groups of immigrants, namely immigrants from the Pacific Islands and immigrants from Hong Kong and Taiwan. The former reside in low socio-economic areas, the latter in higher socio-economic areas in several large Australian cities. When I write the proposal for funding I am struggling with issues about cultural identity. I know my own personal schooling experiences connect with the research knowledge. I had written a few papers about issues of cultural identity, but not undertaken any large-scale empirical work. The papers had been written explicitly for a teacher audience because I was working closely at that time with senior policy officers in a large education bureaucracy who were developing education programs (teacher professional development and curriculum units) on anti-racism and gender equality (Singh, 1994, 1997). The first paper was titled: Generating literacies of 'difference' from the 'belly of the beast'. The second paper was titled: On speaking as an 'Asian' teacher. Gender and cultural inclusion in social education curricula. In both papers, I tried to draw my own personal experiences of schooling in Australia as empirical 
data (method) and connect these with the theoretical literature drawn mostly from Basil Bernstein’s sociological theories of curriculum and postcolonial theories of cultural identity and racism. While my colleagues in the education department considered the papers to be useful to teachers, I wondered whether personal experiences really constituted empirical data. Shouldn't there be a strong demarcation between personal experiences and scientific educational research? Should these papers be categorised as 'scholarship of teaching' rather than 'educational research’?

My efforts to answer these questions guided the way I led the research team in my first large-scale empirical research project. Data for the project were collected from: (1) interviews with community members, parents, teachers; (2) focus group discussions with students; and (3) audio-recordings of classroom lessons. All of this data was going to be analysed by synthesising the theoretical ideas from postcolonial theories and Bernstein’s sociology of education with data analytic strategies from ethnomethodology, particularly conversation analysis. This sounded theoretically and methodologically coherent and doable. All the research team needed to do was: (1) locate/find the two communities - Pacific Islander and Taiwanese/Chinese in the local area; (2) identify key participants from the communities to interview, locate key schools and school personal; (3) design the data collection instruments (interview schedules, focus group questions); (4) work out the best technological devices to get the best possible recordings and then transcriptions. Relatively simple and logical! Right!

But each stage of the data collection, transcription, analysis and reportage stage troubled me and my colleagues. First of all, there wasn't a community out there waiting to be found. Sure schools in certain areas had identified problems, for example, large enrolments of students from the Pacific Islands who did not speak English as a first language. Consequently, these schools needed additional resources, such as English as an Additional Language/Dialect (EAL/D) teaching specialists. But this is where the commonalities in the Pacific Islander student population seemed to begin and end. As we tried to map out the Pacific Islander student population and local communities of Pacific Islanders we found:

\section{Diverse religious groups led by elders and religious ministers (Uniting Church, Assemblies of God,}


2. Diverse migration patterns - some directly from various Pacific Islands (Samoa, Tonga, Cook Islands), some via New Zealand;

\section{Different emphases placed on the importance of retaining Samoan language and cultural identity and learning English language skills}

In addition, as we started to read the research literature on Samoan culture, identity and language practices we became aware of the struggles over representation - the Margaret Mead and Derek Freeman anthropological debate, and the struggles of Samoan/Pacific Islander academics/writers positioning themselves within these debates (see Singh and Dooley, 2001; Singh and Sinclair, 2001).

As a team of researchers we were caught up in these debates and struggles. We could not sit outside of them, on some ledge, looking at these struggles from afar. For example, one of the research assistants on the project team published a letter in the Samoan language in the local Samoan newspaper inviting community members to participate in the research project. One response from a member of the local community, written in English, was to advocate for resources to promote literacy in Samoan language and culture and challenge the racist, colonial legacy inculcated through English language instruction (see Singh and Dooley, 2001).

In addition, as we collected our data, firstly interview data and then classroom lesson data we became aware of the difficulties of capturing/producing 'good enough ' data. Interview data was collected with the assistance of a Samoan research assistant who often translated the research questions into Samoan and then the responses back into English. We kept wondering about what was left out, what was lost in the translations. And furthermore, what was lost as the translations were transcribed from audio-recordings into written scripts, and then selected extracts from these written scripts were represented as a coherent account of our research project. Classroom data was collected by placing a microphone device on the classroom teacher and flat microphones on student desks around the classroom. In addition, a researcher sat in the back of the room and made field notes of the classroom lessons. We interviewed the classroom teachers about their units of work, collected curriculum units of work, lesson plans, lesson handouts, and interviewed 
teachers about their work and how they adapted their lessons to cater for the needs of a culturally diverse student population (see Singh, 2001).

We worried that despite all the technological devices we were using, we still couldn’t capture the complexity of what was going on in the classrooms. We spoke to technicians about our concerns and ordered more sophisticated technologies in our efforts to capture student discussions, asides, one-on-one classroom interactions. We hoped that these technologies would enable us to capture the multi-layered patterns of classroom communication. But no matter how complex the technologies we introduced, capturing the messy, fluid, 'real world' kept eluding us. And then we had to transcribe all this data, and again select segments of it, to tell some kind of story, some kind of account.

Our papers published at that time capture our struggles over the politics of representation - who can represent whom, and the distinction between representation as delegation and depiction (Singh and Dooley, 2001). But at this stage of the research journey we still saw ourselves as researchers apart from the researched, that it was our job to remain objective, distanced, and removed from the researched. We tried to take some kind of helicopter view of the researched - a view that hovered above all the literature written on this topic, a view that hovered above the ‘community’ of schools, participants and so forth.

But I kept wondering about the location of the researcher, the research team, and the instruments of research, in the accounts of schools and local communities. It seemed odd that I had started exploring this topic of cultural identity and schooling by drawing on my personal experiences as empirical data, but then had tried so hard to completely erase myself from the research work. What was going on here? What types of research enactments were being produced by thinking about research practices in this way?

\section{(Insert Parlo Slide 1 here)}

\section{(Insert Stephen Slide One [jpeg file] here)}

Stephen: Thanks Parlo. The interesting part of my research journey starts about two thirds of the way through my PhD (conferred in 2013, twenty years after Parlo’s!) when I realised that I was stuck. I could not move forward with the research because I was not satisfied with the possibility of, or able to employ, a set of theoretical and methodological ideas that were both tenuously connected to one another and aimed at 
revealing the 'conditions' of others. And even more problematically (it seemed to me at that time) that allowed (forced?) me to 'analyse' the words of other people as 'concepts' that would then fall into themes and so on. And that these would then coalesce into some sort of 'findings'. It seemed to me that if I continued with this kind of research all I would be producing was a kind of big lie, or a 'real fabrication' to put it more poshly.

These fabricated findings, I thought, would not say anything at all about what was going on apart from what the researcher (me) wanted to reveal - which in the end is about my own interests (get a PhD asap)- irrespective of how I might position myself or how much ‘justice’ I was striving for on behalf of others. I was stuck between some beautiful theory and some methods that did not make sense to me as honest and reliable ways in which to say anything that matched the elegance and power of the theoretical work that I had read (mainly Bourdieu with a bit of Foucault), nor the complexity and emergent qualities of the situations that arose in the processes of doing the research.

I have worked then in this quandary-space and expanded it into processual idiotic (Michael , 2012) wondering/wandering (Stengers, 2007); which despite its seeming negative connotations, I argue might be an essential characteristic of contemporary scholarship that aims to dwell seriously with the concerns of others and make a lasting difference to/ with respect to intractable social problems. But this is a big argument to make so I will just rather cheekily leave it there to be followed up in later publications!

However, in this process of expanding the quandary-space I have become very interested in learning more about how other people work out these issues (of representation, of theory-method resolution, of the point of doing research). I have had plenty of people tell me I am wrong about my quandaries and that it is necessary and important to do rigorous analysis and revelation. I am sure this is right and in fact I think that a lot of good political work is done through some research that allows the conditions of others to become well-known and to be made public (for example the way that statistics are useful in documenting and analysing the extent and forms of poverty, see Desrosières, 2014). This is important work.

Some of the ideas that I have stumbled into and that might contribute to stumbling being or becoming a positive approach to research work include experimental constructivism (Whatmore, 2013), 
intra-activity (Barad, 2007) and the relations between presupposing an equality of intelligences, equality, politics and emancipation drawing on the work of Jacques Rancière (see for example Rancière, 1991, 1999, 2010). Chris Bigum (see http://pubclickped.wikidot.com/ and http://www.chrisbigum.com/cj/About ) has said that theory is just a thing that is good to think with. I like this definition and each of these ideas have helped me to think a bit differently. But most importantly, they have helped me to put into a kind of crisis the boundaries between theory, method and data which I think is an essential first step. They help me especially to ask how to do research work 'in' and 'on' 'worlds'? This raises questions about purposes, positions, processes which I now think are essential to keep in the foreground of all research.

But to get back to your point, Parlo, about re-presentations, the thing for me about it is partiality. There is always something left out - or to think of it positively more to add. This is a purposes and process issue. And it is always dis-positional. This is a position issue - where is the researcher in regard to their objects? what is the relation (Heimans, 2016)?

About dis-position, I want to say positioned and embodied. In a place. But it is more than this. It is intra-connected. And this opens up to thinking about a wide gambit of relationality. So, following Barad (2007), intra- is the inverse of inter-. Inter- is about relations between two pre-existing entities. Intra- is about how entities form out of relations - what phenomena emerge out of relations. Partiality then is neither good nor bad, but a place to begin adding to - out of relations, to begin working with always 'in relation' phenomena. So now, and what is emerging out of my current research, is the need to develop new relational methodologies that are relational 'all the way down'. For example, the 'intra-view' or 'intra-sensorium' is an idea that Ben Williams (see Williams and Macdonald, 2015) and I are currently working on and fleshing out that is aimed at taking a line of flight out of the subservience of the visual in metaphors of understanding, as opposed to the interview (see Heimans and Williams, in progress).

But I need to join the dots more. I know (I have been told) that what I say is too much jargon. Too theoretical! Funny, I see it the opposite way. For example, I have always been interested in practice. Because what people do and why they do it is interesting, and confusing. So I have worked out from 'simple' ideas and explored various pathways to try to do work on this - what people do (how, with what) 
and why. I try to find ideas that are simple, but simply work in the world the opposite to the ways that it appears to me are 'current'. I am looking for counterfactual-making resources - resources of discomfort. To me these are very practical, even if quite dense conceptually. Maybe what is not clear is the thinking that has led to wanting to read this kind of 'difficult' work. So if I try to unpack what lead me to thinking with Barad (2007) (for example) it was part of a long journey around substantialist-relational work on the one hand and representation-performance (on the other). First, I wanted to fill my head with resources that gave me ways to think about relations. For me this began with Bourdieu and the relationality of his various conceptual schemas. This is what first drew me to his work. But after reading most of this work, I did not like the politics of the writing; it was far too didactic. The difficulty that I have with Barad is different. Her work is too universalising and it is no surprise that she comes from the heartland, the centre of the Global North's knowledge production machine whose function is to create universal schemes from partial ethno-scapes (see Connell, 2007 on Southern Theory). Second, I wanted to be able to think about process. How did things come to be, and to change, and to keep changing (an essential resource here is the work of Alfred North Whitehead (see Mesle, 2008 for a readable introduction). And then how is it possible to do research that is unsubstantial/processual, especially when the need for 'findings' is so hegemonic? This question leads to problems of representation, which takes us down the line of needing to talk about metaphysics. Which we won't do. Representation for me, to cut to the chase is essential, in fact unavoidable, but it is not ever about saying something about a separated out external world. Not speaking on behalf of it, or others. Nor, more crucially is it about revealing something to someone else about something or someone else. (And here I begin to part company from people who use the work of someone like Bourdieu (e.g. (Bourdieu, 1977)relational work, to make claims that 'fix' things- in both sense of the word- that is hold them still, through revealing things via research [and its various tight, but usually opaque methods] and 'correct' them- so that carry a moral undertone). Representations (like what we are doing now for example), we learn from nonrepresentational theorising, are performative. That is they are part of the various 'worldings' that we (and not just us humans (Latour, 2005)) are all always mixed up in.

The distinction between representational and non-representational 'theory' (see Thrift, 2008) is part of an emerging debate, hinted at already, and being taken up in education research concerning questions of 
ontology and relations with epistemology - of making explicit connections between the two. To put it crudely, representationalist research assumes an ontological externality that is knowable and able to be represented by the procedures of research (whether these are qualitative or quantitative, and whether these are epistemically diffident or not). Non-representationalist research on the other hand involves taking into account the relations between ontology and epistemology. It troubles the assumption of externality and brings into the equation the performative aspects of research - how research performs 'worlds', as opposed to (in representationalist mode) how research reveals aspects of 'the' 'world'. Of course this is just one way of characterising this debate and there are many other thinkers whose work is important to consider here, for example Deleuze and Guattari, Alfred North Whitehead, Erin Manning and Brian Masumi (see Manning and Massumi, 2014). But this is just one debate in a broader spectrum of emerging theory-method questions.

\section{(Insert Parlo Slide 2 here)}

Parlo: How interesting Stephen. I have also been struggling with notions of representation and performativity. The slide presented above maps out two different views of theory generation in the early days of my own research journey. I find that this mapping of the relation between theory-method is still commonly used to teach research students about the theory-method nexus. The slide suggests that theory is generated from the ground up from the data - grounded theory, and is also generated from a synthesis of the

research literature. New knowledge, original contributions in doctoral research, are supposedly generated by addressing the 'gap' in theory, in methods, and/or the 'theory-method' nexus.

Stephen: So, you think it is good, or a 'good', in Law 's (2004) terms to recognise interconnections, and to think with these creatively. The sort of research I am drawn to is similar. However I am very interested in troubling the alignment between presumed capacities and positions - a radical disagreement after Rancière’s thinking (see Rancière (1991) for a good introduction). Bruno Latour gives an example of how Spanish invaders in the Americas cut off the heads of the 'natives' to see if they had souls, and the 'natives' cut off the heads of the Spanish to see if they had bodies. So for me thinking about research and theory-methods and data concerns more than recognizing the 'other' or with working together with others, or being linked to 'other' thinkers collegially, intellectually or ideationally. It is more like what Helen Verran says: that “when 
radically different metaphysics intersect, their disjunction is experienced as bodily disconcertment” (from Law and Lin, 2010). A bodily disconcertment, twisting... (Heimans, 2016).

\section{(Insert Stephen Slide 2 [jpeg file] here)}

Parlo: I have spent a lot of time thinking about these ideas about theory building, knowledge building, and the project of the sociology of education. I was fortunate to have spent some time working with Basil Bernstein in the 1980s and 1990s at the Institute of Education, University of London. Bernstein (1975, 1990) was building maps and models of pedagogic communication. He examined the specialized communication codes of schooling systems and focused on the types of knowledge (curriculum) taught in these systems. He also examined the specialised pedagogic codes of classroom and school communication, and mapped out pedagogic modes.

I was interested in these maps/models that Bernstein had constructed as explanatory devices, but thought he hadn't taken account of the feminised nature of the teaching workforce and how this might produce gendered communication codes. So I read a lot of the feminist poststructuralist literature and tried to synthesise this with Bernstein’s theories of pedagogic discourse to map out theoretical resources to help me think about my research problems. This is what led me to trying to map out what Bernstein and colleagues were doing, and where I thought there was room for additional work (see Singh et al., 2016).

Stephen: Fascinating. It is interesting that you could see a blind spot in someone as 'big' and generative as Bernstein. As a newbie, I have tried to craft things out of disconnections mainly. Of not putting things together. I am not sure about models and maps. I am interested in the clash or the sparks of the incommensurabilities of thinking. The cracks. One of these cracks that is opening for me is about explanation. In my $\mathrm{PhD}$ the triumvirate of interpretation and analysis and explanation came undone. And now I am utterly uninterested in explanation. I think the desire for explanation has created a lot of problems. One of these is that it has allowed some people to build on the relations between power and knowledge to create and maintain positions that float 'above' others to become the great explainers of others' conditions (not always to these others!). 
Another crack is that I don’t see the kinds of work I want to do as being about building (knowledge) in a traditional sense (and this crack is connected to doing non-explaining research). More like gathering, or what Tim Ingold (2007) calls alongly knowledge wayfaring (a kind of journey where the end is unspecified). And in this wayfaring I will encounter/create situations where my thinking is put at risk, has to be put at risk to the situations. This is one reason I need a varied, multilayered dance of theory-methods. I have to be able to bring a lot to situations, because my place, my position can never be guaranteed by being a 'researcher' from a university. This position has to be put at risk as well. So the alignment between my position and my capacity has to be put at risk to situations. I guess a lot of this relates to purposes and position as well. Why do research? I say not knowledge building. Unless it is knowledge that is built with the radical equality of others (an example soon) and unless it has been put to multiple risks along the way. And that it is open to ongoing interrogation and 'misunderstanding'. It is not for 'transmission', as transmission, or 'learning' equates with the presupposition of a lack in the learner (see Biesta, 2014 and Rancière, 1991).

For me then it is more about being open to the accidental adventure of thinking. In an interview with Rancière (http://www.tate.org.uk/context-comment/audio/jacques-ranciere-conversation-clairebishop) he was asked about how he developed his thinking about equality and politics (for him they are related). Thinking about equality came after about ten years of work on the texts of workers - their poetry, their literary writings. And politics? Because someone asked him one day to write about what he thought about politics. So he thought about it and wrote down what he thought. (Key Rancièrian questions are "What do you see?" "What do you think/or make of it?” (see Biesta, 2014)). He did not set out to devise a theory of politics (or of anything for that matter). He thought about what politics might be given the presupposition of equality (that the workers' texts showed). It was as accidental as that. But of course this 'accident' is not quite as simple as it sounds or may appear. What he 'thought' is not something that just popped into this brain as a kind of new age creative urge. No it was based on careful, painstaking, long and slow thinking work. Slow, long thinking work with 'others' (for example the texts of workers, with a provocateur who asked about politics).

One realist possibility I think (just really thinking 'out loud’ now) is experimental constructivism. Based on philosopher of science Isabelle Stengers' thinking and the subsequent work done by geographer 
Sarah Whatmore and colleagues (see Whatmore and Landström, 2011). Isabelle was a chemist, who has worked with a famous Nobel-prize winning physicist (Ilya Prigogine) to write the book Order Out of Chaos, who has become a philosopher drawing on (amongst others) Deleuze and Guitarri and Whitehead (so, process thinking work).

Whatmore has developed a way of doing research that gathers together disparate elements that (in my mind) offers opportunities for contra-diction. So her work with a small town in England on flooding is an example. In this case there was a knowledge controversy about how to solve the (now becoming more regular in the Anthropocene) problem of flooding. She instigated a process where expert knowledge about flooding was put to the test. Where the ideas of people WHO ARE MOST AFFECTED BY A PROBLEM are integral to the process. Where solutions are proposed, modeled prototyped and tested out. And made public - made open to further ideas, to generating new publics; to gathering new people to them who are also affected by the problem (but who paradoxically are not representative of others- who do not speak in others names. For others). Who have a deep desire for change, for a solution. This is slow and gradual work. Solutions take time to emerge and to take shape. They are literally unforeseeable (indeterminate). Expert knowledge is brought in and put to the test in this milieu. In the process knowledge 'interests' are revealed. The people in politics who are in cahoots with business. The university and engineering people who are behind the proposal to build the dam wall (that no one wants-and would not have worked anyway). And so on. Here we begin to see some contra-dicting. Some thinking and speaking against.

Parlo: My first big large scale research project was funded in 1996. I took up a Head of School (HoS) of Education position in a university ten years later in 2006. Most of my research theoretical work, prior to taking on the role of Head of School had been from a critical sociological disciplinary framework. But as I took up the role of HoS I found that critique, at least critique from the critical sociology of education tradition, just didn’t cut it anymore. It couldn’t help me answer challenging questions from school principals, union representatives, policy makers and so forth. For the past ten years, I have worked in research teams and in partnership with schools servicing high poverty communities to make a difference to students' learning attainment. The theory-method approach I have adopted is co-inquiry, design-based research. 
You (turning to Stephen) introduced me to ideas from philosophy: enactment, performativity, ontological politics. I think one of the most significant things I learnt from you, Stephen was: research is not something done from afar, from a God's eye point of view, theory is not a lens from which to collect and analyse data. Rather theory is a set of ideas to think with, about, and this thinking is performative, it performs new realities (see Heimans et al., 2015; Singh et al., 2014). The ideas that I am grappling with right now are Barad’s (2007) ethico-onto-epistemology and emergent realisms, and Mol’s (2014) relational realities.

My journey through different theory-method approaches has involved the constant making and remaking of research maps. It has been, and continues to be, a difficult, challenging journey. But this hard work is often dismissed as theoretical jargon, of not connecting to the 'real world' of schools and teachers, of not being practical enough.

Stephen: My answer is that these are not theoretical ideas, but very practical ones. For example if you go into a school thinking that you can fix it, you do so with certain presuppositions about who knows what, about what (that is you have already allocated and aligned positions and capacities), who can do what, when, and how. The ideas that I am interested in open these presuppositions up to question, so they open space for both disagreement and careful and difficult composition. I do not think that these are trendy or that this is a game. Who can say what about what, who has naming rights, how those whose only part is to have none ‘the part of the no part’ (Rancière, 2007), and how 'research’ buys into this: these seem to me to be very serious questions. And ones worthy of pausing to discuss, fight about, raise questions about visibility - what is visible, in whose name, who has done this naming? For example, the local radio station I listen to asked a question about what you thought when you saw Scott Morrison deliver the budget speech. What I thought is... too many white men in suits... too many members of the political class... too many fabulations to protect power and interests... no mechanisms for real dissensus. One question this raises is how to get white men, who have the 'right to rule' (the oligarchs of consensus politics (see Rancière, 2006)) out of the picture, how to get the political class ruptured, how to start doing research that contra-dicts what research is for, who it is for, and what comes next.... Yes, old questions surely, of critical scholarship that continues to demand new and creative responses. 


\section{(Insert Stephen Slide 3 here [jpeg file])}

\section{'Post' script}

Is this a post-method, post-theory (post qualitative (St. Pierre, 2011)) condition we are struggling to perform in an emergent post-global, spatio-temporal 'fix’ (Jessop, 2003)? So called 'social’ problems remain intractable (Fairclough, 2009) and new ones appear just as wickedly, reconfiguring the converging 'wenesses' of globalising cosmopolitan sensibilities. If we can think 'emergently', and slow down the presumptions we (Parlo and Stephen) hold about the alignment in research of places, positions and capacities (that Rancière’s writing helps bring into question), will this allow a staging for dissensus (Rancière, 2010), for an emerging cosmo-political (Stengers, 2005) subjectivity, for us as researchers and the others we surely must intra-act with? The answer is doggedly indeterminate (Barad, 2007), and arrives as lures to the future (Mesle, 2008), as we feel our way together with multitudinous protagonists, toward a slowed down rationality in ever-changing incremental compositions.

It is difficult to capture all that happened when we enacted these messy (see Law, 2004) theorymethod journey stories at the workshop. But of course 'capture' is not the point - or not all that might be done. How might we attune with/to (Manning and Massumi, 2014) all the talk, the subtleties of body language, vibes, energy, feelings, boredoms, and so on, of the 50 or so participants at the workshop, as well as the messages that were exchanged via twitter and other social media forums during and after? How might we compose new connections, create new theory-methods that come to matter (Barad, 2007)?

\section{References}

Barad, K. (2003). Posthumanist Performativity: Toward an Understanding of How Matter Comes to Matter. Signs: Journal of Women in Culture and Society, 28(3), 801-831. doi:10.1086/345321

Barad, K. (2007). Meeting the universe halfway quantum physics and the entanglement of matter and meaning. Durham: Duke University Press.

Berlant, L (2011). Cruel Optimism. Durham: Duke University Press

Bernstein, B. (1975). Towards a Theory of Educational Transmissions (Class, Codes and Control Vol 3). London, Routledge \& Kegan Paul. 
Bernstein, B. (1990). The structuring of pedagogic discourse. London, Routledge.

Biesta, G. J. J. (2014). The Beautiful Risk of Education: Paradigm Publishers.

Bourdieu, P. (1977). Outline of a theory of practice. Cambridge; New York; Melbourne: Cambridge University Press.

Desrosières, A. (2014). Statistics and social critique. PARTECIPAZIONE E CONFLITTO, Available at: <http://siba-ese.unisalento.it/index.php/paco/article/view/14157> . Date accessed: 26 Jul. 2016.

Fairclough, N. (2009). Language and globalization. Semiotica, 2009(173). doi:10.1515/semi.2009.014

Heimans, S. (2011). Education Policy, Practice, and Power. Educational Policy, 26(3), 369-393. doi:10.1177/0895904810397338

Heimans, S. (2012). Coming to matterinpractice: enacting education policy. Discourse: Studies in the Cultural Politics of Education, 33(2), 313-326. doi:10.1080/01596306.2012.666083

Heimans, S. (2015). Taking a material turn in education policy research? . In M. Clarke, K. N. Gulson, \& E. B. Petersen (Eds.), Education Policy and Contemporary Theory: Implications for Research. London: Routledge.

Heimans, S. (2016). Fieldwork in philosophy, emancipation and researcher dis-position: A post-qualitative research exemplar. Qualitative Research Journal, 16(1), 2-12. doi:doi:10.1108/QRJ-08-2014-0035

Heimans, S., Singh, P., \& Glasswell, K. (2015). Doing education policy enactment research in a minor key. Discourse: Studies in the Cultural Politics of Education, 1-12. doi:10.1080/01596306.2015.1074428

Heimans, S., \& Williams, B. J. (in progress). From inter- view to intra-sensorium? Process-relational method-work. Qualitative Inquiry.

Ingold, T. (2007). Lines: a brief history. London; New York: Routledge.

Jessop, B. (2003). The Spatiotemporal Dynamics of Capital and its Globalization - and how they Challenge State Power and Democracy. Retrieved from Lancaster: URL?

Latour, B. (2005). Reassembling the social: an introduction to actor-network-theory. Oxford; New York: Oxford University Press.

Law, J. (2004). After method: mess in social science research. London; New York: Routledge. 
Law, J., \& Lin, W.-y. (2010). Cultivating disconcertment1. The Sociological Review, 58, 135-153. doi:10.1111/j.1467-954X.2011.01966.x

Manning, E., \& Massumi, B. (2014). Thought in the Act: Passages in the Ecology of Experience. Minneapolis: University of Minnesota Press.

Mesle, C. R. (2008). Process-Relational Philosophy: An Introduction to Alfred North Whitehead: Templeton Press.

Michael, M. (2012). “What Are We Busy Doing?”: Engaging the Idiot. Science, Technology \& Human Values, 37(5), 528-554. doi:10.1177/0162243911428624

Mol, A. (2014). Relative Realities, Theoretical Sensitivities. Forum for Social Sciences and Philosophy, Techno -scientific worlds in social sciences. J. Zahle. Department of Philosophy, Department of Media, Cognition and Communication, University of Copenhagen, https://vimeo.com/108273539.

Rancière, J. (1991). The ignorant schoolmaster: five lessons in intellectual emancipation. Stanford, Calif.: Stanford University Press.

Rancière, J. (1999). Dis-agreement: politics and philosophy. Minneapolis: University of Minnesota Press.

Rancière, J. (2006). Hatred of democracy (S. Corcoran, Trans.). London; New York: Verso.

Rancière, J. (2007). What Does it Mean to be Un? Continuum, 21(4), 559-569. doi: http://dx.doi.org/10.1080/10304310701629961

Rancière, J. (2010). Dissensus: on politics and aesthetics (S. Corcoran, Trans.). London; New York: Continuum.

Singh, P. (1994). Generating literacies of 'difference' from the 'belly of the beast'. Australian Journal of Language and Literacy, 17(2), 92-100.

Singh, P. (1997). On speaking as an ‘Asian’ teacher. Gender and cultural inclusion in social education curricula. Education Links, 54, 11-15.

Singh, P. (2001). Pedagogic Discourses and Student Resistance in Australian Secondary Schools. In A. Morais, I. Neves, B. Davies, \& H. Daniels (Eds). Towards a sociology of pedagogy. The contribution of Basil Bernstein to research (pp. 251-276). New York: Peter Lang. 
Singh, P. \& Dooley, K. (2001). Accounting for Educational Equality. The cultural politics of Samoan paraprofessionals' representations of pedagogy in state designated disadvantaged schools and communities. Journal of Curriculum Studies, 33(3),335-362.

Singh, P., Heimans, S., \& Glasswell, K. (2014). Policy enactment, context and performativity: ontological politics and researching Australian National Partnership policies. Journal of Education Policy, 29(6), 826-844. doi:10.1080/02680939.2014.891763

Singh, P., Pini, B., Glasswell, K. (2016, forthcoming). Recontextualising Education Leadership Discourses: Revisiting Gendered Code Theory. Gender and Education.

St. Pierre, E. (2011)). Post Qualitative Research: The Critique and the Coming After. In N. Denzin \& Y. Lincoln (Eds.), The Sage handbook of qualitative research (pp. 611-626). Thousand Oaks: Sage.

Stengers, I. (2005). The Cosmopolitical Proposal. In B. Latour \& P. Weibel (Eds.), Making Things Public. Atmospheres of Democracy (pp. 994-1003). Massachusetts: The MIT Press.

Stengers, I. (2007). Diderot's Egg: Divorcing Materialism from Eliminativism. Radical Philosophy (144), 715.

Thrift, N. (2008). Non-representational theory: space, politics, affect. Milton Park, Abingdon, Oxon; New York, NY: Routledge.

Whatmore, S. (2013). Earthly Powers and Affective Environments: An Ontological Politics of Flood Risk. Theory, Culture \& Society. doi:10.1177/0263276413480949

Whatmore, S., \& Landström, C. (2011). Flood apprentices: an exercise in making things public. Economy and Society, 40(4), 582.

Williams, B. J., \& Macdonald, D. (2015). Explaining outsourcing in health, sport and physical education. Sport, Education and Society, 20(1), 57-72. doi:10.1080/13573322.2014.914902 